leaving only the areas of dark metallic silver to form the photographic image. ${ }^{2}$

The connection between this process and alkaptonuria becomes clearer when one examines the molecular structures of hydroquinone (a widely used developer present, for example, in Kodak D11 and D76) and homogentisic acid (Fig. 2).

As a developer, the paired hydroxyl $(\mathrm{OH})$ groups on the benzene ring serve to reduce the silver ions. The effectiveness of homogentisic acid in this process was noted as early as 1942 by Fishberg, who proposed its use as a specific test for "the instantaneous diagnosis of alkaptonuria on a single drop of urine." 3 It should be noted that, although the fundamental requirement for a developer is that it be a reducing substance, the process is rendered more efficient in the usual commercial developers by the addition of a number of other chemicals. These obviously are lacking in urine, which probably accounts for the restricted range of contrast evident in Fig. 1. An intriguing speculation is the role played by the pigment formed as the homogentisic acid oxidizes, either in contributing to the overall cast evident in the photograph or to the image itself.

My father never published this experiment, but the same concept was applied by Scott Williams and his students in the 1995 Technical Photographic class at the Rochester Institute of Technology. ${ }^{4}$ They used coffee as a developer, affording a new use for the cold dregs at the end of a long day. One of Williams' students subsequently extended the concept, using an infusion of mint, which proved to be an even more effective de- veloper, in addition to producing olfactorily enhanced prints, ${ }^{5}$ perhaps an advantage over the urine of ochronotic patients.

David Maxwell

Department of Family Medicine

Dalhousie University

Halifax, NS

\section{References}

1. La Du BN. Alkaptonuria. In: Scriver CR, Beaudet AL, Sly WS, Valle D, editors. The metabolic and molecular bases of inherited disease. 8th ed. New York: McGraw-Hill; 2001. p. 2109-23.

2. Glafkidès P. Chimie et physique photographiques. $4^{e}$ éd. Paris: Publications Photo-Cinéma, Paul Montel; 1976. p. $68-80$.

3. Fishberg EH. The instantaneous diagnosis of alkaptonuria on a single drop of urine. 7AMA 1942;119:882.

4. Williams S. That last cup of coffee: photographic developers of last resort for the weary, the bleary, and the unrested. Darkroom \& Creative Camera Techniques 1995;16(5):35-7.

5. Iverglynne D. A biodegradeable development solution and method of use [international patent application no PCT /US/2002/005653]. PCT Gazette 2003 Dec 31. Publ no WO 2004/001504].

\title{
IN THE LITERATURE
}

\section{Is there a role for estrogen in the prevention and treatment of urinary incontinence?}

Hendrix SL, Cochrane BC, Nygaard IE, Handa VL, Barnabei VM, Igesia $C$, et al. Effects of estrogen with and without progestin on urinary incontinence. JAMA 2005;293:935-48.

Background: The role of estrogen in the treatment of urinary incontinence is unclear. Given that the lower urinary tract shares a common embryologic origin with the genital tract, it has been theorized that urinary incontinence may be related to atrophy associated with estrogen loss. However, epidemiologic and trial evidence has shown both beneficial and harmful effects of estrogen on urinary incontinence. ${ }^{1,2}$

Design: This study included 23296 healthy, postmenopausal women aged 50-79 years enrolled in the Women's Health Initiative hormone replacement therapy (HRT) trial and for whom baseline and 1-year data on urinary incontinence (defined as self-reported involuntary urine leakage of any amount in the past year) were available. Women were randomly assigned to receive either placebo or HRT in the form of conjugated equine estrogen $(0.625 \mathrm{mg} / \mathrm{d})$ with or without medroxyprogesterone $(2.5 \mathrm{mg} / \mathrm{d})$ based on their hysterectomy status. Participants, clinic staff and outcome assessors were blinded to group allocation. Primary outcomes were incident urinary incontinence at 1 year among women without baseline incontinence $(N=8255)$ and severity of incontinence among those with urinary incontinence at baseline
$(N=15$ 041). Urinary incontinence was further subdivided by type (stress, urge or mixed). Measurements of severity included self-reported frequency, amount, associated limitations in daily activities and "degree of bother."

Result: HRT was associated with an increased 1-year incidence of all types of urinary incontinence among women who were continent at baseline (Table 1). It was also associated with an increase in the severity of urinary incontinence among women who were incontinent at baseline (Table 2).

Commentary: This large, welldesigned, multicentre, randomized trial appears to resolve the controversy around estrogen and urinary incontinence. The 
results consistently demonstrate that there is no role for estrogen in the prevention or treatment of urinary incontinence, even when the definition of urinary incontinence was altered in a sensitivity analysis.

These findings require us to re-examine the biological effect of estrogen on the lower urinary tract. A recent study ${ }^{3}$ suggested that estrogen may actually alter collagen metabolism, which would result in damage to the periurethral connective tissues essential for effective urethral closure. This would help explain why estrogen had its strongest effect on the development of stress incontinence, which is related to increased urethral mobility, poor intrinsic sphincter function and weakness in the muscles of the pelvic floor.

The Women's Health Initiative trial showed that the risk of developing comorbidities was increased among women taking estrogen with or without progestin. Several of these comorbid conditions could have increased the risk of urinary incontinence, which would explain in part the differences in

Table 1: Relative risk of incident urinary incontinence with estrogen plus progestin and estrogen alone, and associated numbers needed to harm

\begin{tabular}{lcccccr}
\hline \multirow{2}{*}{$\begin{array}{l}\text { Type of urinary } \\
\text { incontinence }\end{array}$} & \multicolumn{2}{c}{ Estrogen plus progestin } & & \multicolumn{2}{c}{ Estrogen alone } \\
\cline { 2 - 3 } \cline { 6 - 7 } & $\mathrm{RR}(95 \% \mathrm{Cl})$ & $\mathrm{NNH}$ & & $\mathrm{RR}(95 \% \mathrm{Cl})$ & $\mathrm{NNH}$ \\
\hline Any & $1.39(1.27-1.52)$ & 11 & & $1.53(1.37-1.71)$ & 8 \\
Stress & $1.87(1.61-2.18)$ & 14 & & $2.15(1.77-2.62)$ & 11 \\
Urge & $1.15(0.99-1.34)$ & 194 & & $1.32(1.10-1.58)$ & 54 \\
Mixed & $1.49(1.10-2.01)$ & 105 & & $1.79(1.26-2.53)$ & 57 \\
\hline
\end{tabular}

Note: $\mathrm{RR}=$ relative risk, $\mathrm{Cl}=$ confidence interval, $\mathrm{NNH}=$ number needed to harm.

Table 2: Relative risk of worsening urinary incontinence with estrogen plus progestin and estrogen alone

\begin{tabular}{lcc}
\hline & \multicolumn{2}{c}{ Treatment group; RR $(95 \% \mathrm{CI})$} \\
\cline { 2 - 3 } Severity measure & Estrogen plus progestin & Estrogen alone \\
\hline Amount & $1.20(1.06-1.36)$ & $1.59(1.39-1.82)$ \\
Frequency & $1.38(1.28-1.49)$ & $1.47(1.35-1.61)$ \\
Limitation in daily & $1.18(1.06-1.32)$ & $1.29(1.15-1.45)$ \\
activities & $1.22(1.13-1.32)$ & $1.50(1.37-1.65)$ \\
Degree of bother &
\end{tabular}

incident urinary incontinence between the placebo and HRT groups.

Practice implications: Although estrogen is no longer a treatment option for urinary incontinence, there are effective alternative treatments. These include pelvic floor muscle exercises, bladder training, prompted voiding, anticholinergic medications and surgery. ${ }^{1}$ Unfortunately, the main barrier to effective management of urinary incontinence is not a lack of treatment options but rather a lack of communication between patients and their health care providers about this problem. ${ }^{4}$

Jayna M. Holroyd-Leduc

Sharon E. Straus

Division of General Internal

Medicine and Geriatrics

University Health Network

Knowledge Translation Program

University of Toronto

Toronto, Ont.

\section{References}

1. Holroyd-Leduc JM, Straus SE. Management of urinary incontinence in women: scientific review. $7 A M A$ 2004;291(8):986-95.

2. Moehrer B, Hextall A, Jackson S. Oestrogens for urinary incontinence in women [review]. Cochrane Database Syst Rev 2003(2):CD001405.

3. Jackson S, James M, Abrams P. The effect of oestradiol on vaginal collagen metabolism in postmenopausal women with genuine stress incontinence. $\mathrm{Br} \mathcal{F}$ Obstet Gynaecol 2002;109:339-44.

4. Ricci JA, Baggish JS, Hunt TL, Stewart WF, Wein A, Herzog AR, et al Coping strategies and health careseeking behavior in a US national sample of adults with symptoms suggestive of overactive bladder. Clin Ther 2001;23:1245-59. 